\title{
Long-term fish community dynamics from a blackwater stream receiving kraft mill effluent between 1973 and 1988
}

\author{
Dianne I. Greenfield ${ }^{1 *}$ \& Henry L. Bart, Jr. ${ }^{2}$ \\ ${ }^{1}$ Marine Sciences Research Center, Stony Brook University, Stony Brook, NY 11794-5000, USA \\ ${ }^{2}$ Tulane Museum of Natural History, Belle Chasse, LA 70037, USA \\ (*Author for correspondence: Tel.: +1-631-632-3029; Fax: +1-631-632-8820; E-mail: dgreenfi@ic.sunysb.edu)
}

Received 2 July 2003; in revised form 10 July 2004; accepted 15 July 2004

Key words: fish diversity, paper mills, kraft mill effluents, blackwater streams, bluegill, mosquitofish

\begin{abstract}
Archived data from a long-term (1973-1988) monitoring study were used to assess the impacts of kraft mill effluents (KME) on fish community dynamics in Elevenmile Creek, a small blackwater stream located in Cantonment, Florida, compared to a neighboring stream, Black Creek, that did not receive KME. The fish community in Elevenmile Creek was generally lower in species richness and diversity than the reference stream. The exception was the mill outfall site, which had similar species richness and diversity to the reference stream. Neither species richness nor diversity changed substantially during the survey period in either stream. Throughout the survey, Elevenmile Creek was numerically dominated by bluegill, Lepomis macrochirus, and eastern mosquitofish, Gambusia affinis. Black Creek had greater abundances of minnows, suckers, and darters. Time series analysis of L. macrochirus for Elevenmile Creek showed that this species was more abundant during winter than summer, but no overall long-term trend was found. Although data used in this study may not be representative of the fish community in Elevenmile Creek as it exists today, results suggest that Elevenmile Creek was highly disturbed during the survey and that species diversity did not increase following mill treatment upgrades.
\end{abstract}

\section{Introduction}

Blackwater streams have a characteristic dark color produced by high allochthonous inputs of organic matter. Effluents from paper and kraft mills (KME) are also high in organic matter (Suntio et al., 1988; Khan \& Payne, 2002), and they can have similar darkening effects upon receiving streams (Davis \& Bortone, 1992; Sharples \& Evans, 2003). When the receiving blackwater stream is small, the relative contribution of discharge to stream volume is high resulting in further darkening of water, increased turbidity, and elevated contaminant levels.

Kraft mill effluents have been associated with adverse effects in fish. Examples of effects that have been related to KME exposure in fish include skeletal deformities (Thulin et al., 1988; Lindesjoo \& Thulin, 1992), swollen kidneys and decreased liver function (Adams et al., 1992, 1993), elevated activity within the mixed function oxygenase system (Khan \& Payne, 1997, 2002), and reproductive abnormalities (Howell \& Denton, 1989; Krotzer, 1990; Davis \& Bortone, 1992; Karels et al., 2001; Sepulveda et al., 2001). Incidences of the latter, specifically masculinization of female mosquitofish, Gambusia affinis, and American eel, Anguilla rostrata, were observed in Elevenmile Creek, Florida, the stream considered for the present study (Howell et al., 1980; Caruso \& Suttkus, 1988). Degree of masculinization, however, may vary seasonally (Cody \& Bortone, 1997).

Not all studies conclude that KME negatively affect fish. For example, Hall et al. (1992) found no 
evidence of neoplasia associated with KME exposure in rainbow trout and Kovacs et al. (2002) found no substantial differences in fish community structure between sites upstream and downstream from mill outfalls. Altered community structure was, however, reported by Livingston (1984) and Karels \& Niemi (2002). Compared to the amount of literature focusing on how KME affect fish physiology, the lack of information and agreement on the consequences for fish communities represents a crucial gap in understanding how KME impact freshwater ecosystems (Jobling \& Tyler, 2003).

Recent papers suggest that specimens and data archived in natural history collections can play a vital role in addressing a variety of societal concerns, including environmental contamination (Suarez \& Tsutsui, 2004). Long-term historical data sets are rare but can provide invaluable information about trends in community structure. The present study is a retrospecitive analysis of fish community dynamics in a KME receiving stream based on fish collection data archived in the Tulane University Museum of Natural History. Considering all the ways KME may affect fish health, it is reasonable to expect that long-term exposure to KME will influence fish community composition. The goal of the current study was to compare the spatial and temporal characteristics of fish assemblages in a KME receiving stream with assemblages in two nearby streams that have no history of receiving KME. Two hypotheses are tested: (1) the $\mathrm{KME}$ receiving stream will have lower fish diversity than reference streams and (2) the KME receiving stream will have a greater proportion of stresstolerant species than reference streams.

\section{Methods}

\section{Study sites and fish collection}

The principle study area, Elevenmile Creek, is a small direct tributary to Perdido Bay near Cantonment, Florida, USA (Fig. 1), draining an area of approximately $133 \mathrm{~km}^{2}$ (Table 1). Elevenmile Creek has received effluents from a paper mill in Cantonment since the 1940s (Livingston 1989, unpublished report). The outfall pipe is situated in the headwaters $5 \mathrm{~km}$ south of the mill. The paper mill (originally the Florida Pulp and Paper
Company) began kraft production in 1941 and merged with the St. Regis Paper Company in 1946. The mill continued to expand from 1946 until 1971, during which time treatment primarily consisted of settling ponds and floating nets to collect rotted fibers. In the 1970s, three new ponds were added for secondary biological treatment and the effluent discharge pipeline and foam control unit that is presently in operation was installed. Champion International purchased the St. Regis Paper Company in 1984, and by 1987 the mill was converted from kraft to $100 \%$ bleached pulp production.

Some water quality characters changed in response to treatment upgrades. For example, in 1971 biological oxygen demand (BOD) decreased at the outfall site from approximately 150 $20 \mathrm{mg} \mathrm{l}^{-1}$ (Livingston, 1989, unpublished report). Total suspended solids averaged $72000 \mathrm{~kg} \mathrm{day}^{-1}$ prior to 1971 but $10600 \mathrm{~kg} \mathrm{day}^{-1}$ after 1971, and a corresponding reduction in turbidity was found. Other water quality characters, such as $\mathrm{pH}$ and conductivity, did not exhibit much change following treatment upgrades, and total effluent concentration can still exceed $50 \%$ of flow (Bortone \& Cody, 1999).

Fish collections used in this study were made by R.D. Suttkus and G.E. Gunning from 1973 to 1988 to monitor the impact of mill discharges on fish and other biota in Elevenmile Creek. Collections were made twice a year (January and July) from four stations (Fig. 1). January samples were not taken during 5 years (1973-1974, 1983, 1985-1986), and July samples were not taken during 1982. The uppermost station (EM1) is located at the mill outfall and drains an area of approximately $16 \mathrm{~km}^{2}$ (Table 1). The outfall is submerged and discharges into a large pool. Above the outfall, the stream is narrow and the water is turbid gray-green. Below the outfall pool, the stream widens and flow increases considerably due to mill discharge, and the water is dark brown. The stream at stations 2 (EM2) and 3 (EM3) is wider and shallower than at EM1. The stream is wider and deeper at station 4 (EM4) than all upstream stations and includes a number of large lateral pools. The substrate at all stations is primarily shifting sand and mud.

Suttkus and Gunning also collected fish from two neighboring blackwater streams during January and July from 1974 to 1982: Pond Creek, which is part of the Escambia Bay drainage, and 


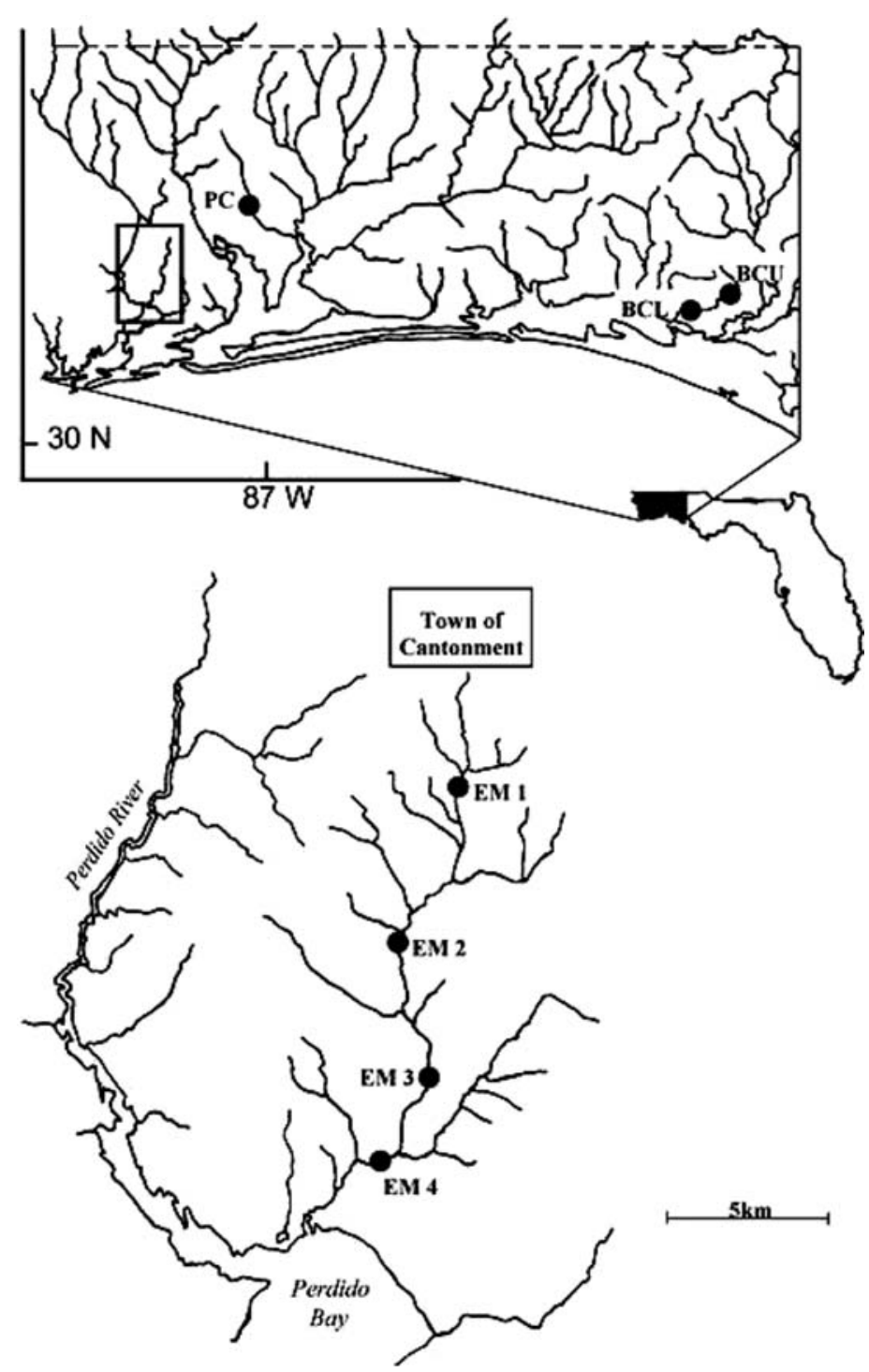

Figure 1. Map of study site in Cantonment, Florida. Stations include Pond Creek (PC), Upper Black Creek (BCU) and Lower Black Creek (BCL). Insert depicts all four stations at Elevenmile Creek (EM1-4).

Table 1. Drainage areas for Elevenmile Creek (EM) and Black Creek (BC)

\begin{tabular}{lcc}
\hline Drainage & Station & Area $\left(\mathrm{KM}^{2}\right)$ \\
\hline EM & 1 & 16.20 \\
& 2 & 57.33 \\
& 3 & 93.91 \\
& 4 & 112.39 \\
BC & Total & 132.59 \\
& Upper & 34.58 \\
& Lower & 114.84 \\
\hline
\end{tabular}

Black Creek, which is part of the Choctawhatchee Bay drainage (Fig. 1). These reference streams have no history of receiving KME. The two stations monitored on Black Creek - Upper Black Creek (BCU) and Lower Black Creek (BCL) - are similar in drainage area to EM1 and EM4, respectively (Table 1), and are compared to these stations. The single station on Pond Creek drains an area comparable to all of Elevenmile Creek $\left(149 \mathrm{~km}^{2}\right)$ and is discussed generally relative to data combined from all four EM stations. Both 
Black Creek and Pond Creek have water quality characteristics typical of blackwater streams in the southeastern US (Livingston 1989, unpublished report), and they are therefore assumed to offer similar habitats to fishes that would have existed in Elevenmile Creek without the impact of effluents. All of the study streams are part of coastal drainage basins that typically have high levels of fish species density (Swift et al., 1986).

\section{Community analysis}

Fish collection data from the Elevenmile Creek, Pond Creek and Black Creek surveys were obtained from the database of the Royal D. Suttkus Fish Collection in Tulane Museum of Natural History in Belle Chasse, Louisiana. To adjust for variability in sampling effort among collections, data were converted to catch per minute of sampling effort $\times 100$ using sampling times from the personal field notes of Suttkus.

Species abundance data were summarized as catch per sampling effort for all 16 years samples are available from Elevenmile Creek and 8 years of samples from Black Creek and subsequently ranked according to their relative abundances. Collection data are presented only for years in which samples for both seasons were taken. To assess differences in community composition, fishes were grouped into five taxonomic and environmental categories at the family level and higher. The groups were CCP species (Cyprinidae, Catostomidae, Percidae, sensu Swift et al., 1986), Centrarchidae, Poeciliidae, 'other freshwater', and brackish fishes. Nomenclature for species names follows Mayden et al. (1992) with one exception, the mosquito fish in the study streams is the eastern mosquito fish (Gambusia holbrooki), but is referred to in this paper as G. affinis for consistency with earlier references to masculinization of female mosquitofish in streams of the eastern Gulf of Mexico.

Comparisons of fish diversity (Shannon-Weaver index, Peet, 1974, 1975) and species richness (number of species) among Elevenmile Creek and reference streams were made for data pooled in four collection periods as follows: period $1=\mathrm{Jul}$ 1974-Jan 1976, period $2=$ Jul 1976-Jan 1978, period $3=$ Jul 1978-Jan 1980, period $4=$ Jul 1980-Jan 1982. Collections from Elevenmile Creek
(1983-1988) were collapsed into two additional time brackets: period $5=$ Jul 1983-Jul 1985, period $6=$ Jul 1986-Jul 1987.

The bluegill sunfish, Lepomis macrochirus, is common in Elevenmile Creek and tolerant of environmental disturbances (Swift et al., 1986; Taylor et al., 1991), including KME (D'Surney et al., 2000). L. macrochirus was therefore used as an indicator of the degree of environmental stress. Time series analysis and population forecasts were performed on mean L. macrochirus abundances in Elevenmile Creek across time periods, within summer and winter seasons, using Minitab Statistical Software, v. 13.31. All other analyses involved standard procedures for non-parametric statistics (Sokal \& Rohlf, 1995).

\section{Results}

The fish community at Elevenmile Creek can be broadly characterized as numerically dominated by the families Centrarchidae and Poeciliidae, particularly Lepomis macrochirus and Gambusia affinis (Table 2). Abundances of other species were comparatively low. L. macrochirus typically accounted for over $60 \%$ of fishes collected from EM1 on any sampling date and was also abundant at the other three Elevenmile Creek stations (48.87\% of the overall survey). By comparison, CCP species were $<5 \%$ of fishes collected from Elevenmile Creek on any sampling date and $3.7 \%$ of the overall survey, and numbers of CCP species were particularly low at EM1. The most abundant CCP species in Elevenmile Creek was the weed shiner, Notropis texanus, which represented $2.2 \%$ of all fishes collected from Elevenmile Creek. By contrast, CCP species, particularly minnows, were abundant in Black Creek (30.86\% of overall survey). CCP species were the numerically dominant group at Pond Creek. Members of the family Centrarchidae usually comprised $<10 \%$ of collections from BCU and $<30 \%$ of the assemblage at BCL on any given sampling date. Other families, such as Fundulidae and Esocidae, tended to be more abundant in Black Creek and Pond Creek than Elevenmile Creek. Brackish species were rare in the upper portions of Elevenmile Creek and Black Creek (EM1 and BCU), but mullet, Mugil cephalus, soles (Achiridae) and drums, (Sciaenidae), were common in the lower stations (EM4 and BCL). 
Table 2. Total number of fish species found in Elevenmile Creek and Black Creek, Florida, grouped according to Cyprinidae, Catostomidae and Percidae (CCP), Centrarchidae, Poeciliidae, other freshwater, and Brackish and ranked according to their overall relative abundances. Species with similar abundances are ranked alphabetically. Elevenmile Creek data represent a 16-year collection period whereas Black Creek data represent an 8-year collection period

\begin{tabular}{|c|c|c|c|c|c|c|}
\hline \multirow[t]{2}{*}{ Group } & \multirow[t]{2}{*}{ Species } & \multicolumn{2}{|c|}{ Elevenmile creek } & \multicolumn{2}{|l|}{ Black creek } & \multirow[t]{2}{*}{ Species total } \\
\hline & & \#Individ & $\%$ Abundance & \#Individuals & $\%$ Abundance & \\
\hline \multirow[t]{16}{*}{$\mathrm{CCP}$} & Pteronotropis hypselopterus & 0 & 0.00 & 2800 & 21.72 & 2800 \\
\hline & Etheostoma fusiforme & 14 & 0.07 & 614 & 4.76 & 628 \\
\hline & Notropis texanus & 456 & 2.20 & 87 & 0.67 & 543 \\
\hline & Notemigonus crysoleucas & 88 & 0.43 & 80 & 0.62 & 168 \\
\hline & Percina nigrofasciata & 143 & 0.69 & 0 & 0.00 & 143 \\
\hline & Erimyzon sucetta & 14 & 0.07 & 128 & 0.99 & 142 \\
\hline & Notropis petersoni & 7 & 0.03 & 103 & 0.80 & 110 \\
\hline & Etheostoma stigmaeum & 0 & 0.00 & 89 & 0.69 & 89 \\
\hline & Etheostoma edwini & 16 & 0.08 & 40 & 0.31 & 56 \\
\hline & Pteronotropis signipinnis & 25 & 0.12 & 4 & 0.03 & 29 \\
\hline & Notropis maculatus & 0 & 0.00 & 19 & 0.15 & 19 \\
\hline & Minytrema melanops & 0 & 0.00 & 6 & 0.05 & 6 \\
\hline & Etheostoma davisoni & 0 & 0.00 & 3 & 0.03 & 3 \\
\hline & Etheostoma colorosum & 0 & 0.00 & 3 & 0.03 & 3 \\
\hline & Cyrprinella venustus & 2 & 0.01 & 1 & 0.01 & 3 \\
\hline & Group total & 765 & 3.70 & 3977 & 30.86 & 4742 \\
\hline \multirow[t]{16}{*}{ Centrarchidae } & Lepomis macrochirus & 10154 & 48.87 & 979 & 7.59 & 11133 \\
\hline & Lepomis gulosus & 734 & 3.53 & 217 & 1.68 & 951 \\
\hline & Lepomis punctatus & 380 & 1.83 & 564 & 4.38 & 944 \\
\hline & Enneacanthus gloriosus & 0 & 0.00 & 928 & 7.20 & 928 \\
\hline & Pomoxis nigromaculatus & 127 & 0.61 & 721 & 5.59 & 848 \\
\hline & Micropterus salmoides & 607 & 2.92 & 166 & 1.29 & 773 \\
\hline & Lepomis microlophus & 241 & 1.16 & 389 & 3.01 & 630 \\
\hline & Lepomis marginatus & 145 & 0.70 & 99 & 0.77 & 244 \\
\hline & Amboplites ariommus & 5 & 0.03 & 15 & 0.11 & 20 \\
\hline & Lepomis gulosus $\times$ macrochirus & 17 & 0.08 & 0 & 0.00 & 17 \\
\hline & Lepomis cyanellus & 14 & 0.07 & 0 & 0.00 & 14 \\
\hline & Lepomis macrochirus $\times$ Lepomis & 8 & 0.04 & 0 & 0.00 & 8 \\
\hline & Lepomis gulosus $\times$ cyanellus & 7 & 0.03 & 0 & 0.00 & 7 \\
\hline & Lepomis gulosus $\times$ marginatus & 6 & 0.03 & 0 & 0.00 & 6 \\
\hline & Lepomis sp. (?hybrids) & 4 & 0.02 & 0 & 0.00 & 4 \\
\hline & Group total & 12449 & 59.92 & 4078 & 31.62 & 16527 \\
\hline \multirow[t]{3}{*}{ Poeciliidae } & Gambusia affinis & 5127 & 24.67 & 2085 & 16.18 & 7212 \\
\hline & Heterandria formosa & 0 & 0.00 & 494 & 3.83 & 494 \\
\hline & Group total & 5127 & 24.67 & 2579 & 20.01 & 7706 \\
\hline \multirow[t]{5}{*}{ Other freshwater } & Labidesthes sicculus & 229 & 1.10 & 675 & 5.23 & 904 \\
\hline & Fundulus chrysotus & 205 & 0.98 & 537 & 4.17 & 742 \\
\hline & Fundulus escambiae & 0 & 0.00 & 320 & 2.48 & 320 \\
\hline & Ameiurus natalis & 255 & 1.23 & 5 & 0.04 & 260 \\
\hline & Elassoma okefenokee & 0 & 0.00 & 248 & 1.93 & 248 \\
\hline
\end{tabular}


Table 2. (Continued)

\begin{tabular}{|c|c|c|c|c|c|c|}
\hline \multirow[t]{2}{*}{ Group } & \multirow[t]{2}{*}{ Species } & \multicolumn{2}{|c|}{ Elevenmile creek } & \multicolumn{2}{|l|}{ Black creek } & \multirow[t]{2}{*}{ Species total } \\
\hline & & \#Indivic & $\%$ Abundance & \#Individuals & $\%$ Abundance & \\
\hline \multirow[t]{21}{*}{ Other freshwater } & Anguilla rostrata & 221 & 1.07 & 0 & 0.00 & 221 \\
\hline & Ameiurus nebulosus & 155 & 0.74 & 0 & 0.00 & 155 \\
\hline & Noturus leptacanthus & 20 & 0.10 & 128 & 0.99 & 148 \\
\hline & Aphredoderus sayanus & 40 & 0.19 & 71 & 0.55 & 111 \\
\hline & Noturus gyrinus & 25 & 0.12 & 74 & 0.57 & 99 \\
\hline & Elassoma zonatum & 65 & 0.32 & 11 & 0.09 & 76 \\
\hline & Ictalurus punctatus & 39 & 0.19 & 0 & 0.00 & 39 \\
\hline & Elassoma evergladei & 20 & 0.10 & 14 & 0.11 & 34 \\
\hline & Noturus funebris & 3 & 0.02 & 25 & 0.19 & 28 \\
\hline & Gobionellus shufeldti & 22 & 0.11 & 0 & 0.00 & 22 \\
\hline & Lepisosteus oculatus & 14 & 0.07 & 8 & 0.06 & 22 \\
\hline & Icthyomyzon gagei & 0 & 0.00 & 21 & 0.17 & 21 \\
\hline & Esox americanus & 13 & 0.06 & 7 & 0.06 & 20 \\
\hline & Esox niger & 0 & 0.00 & 17 & 0.13 & 17 \\
\hline & Ictalurus catus & 17 & 0.08 & 0 & 0.00 & 17 \\
\hline & Fundulus cingulatus & 0 & 0.00 & 14 & 0.11 & 14 \\
\hline & Lepisosteus osseus & 6 & 0.03 & 5 & 0.04 & 11 \\
\hline & Leptoleucania ommata & 4 & 0.02 & 7 & 0.06 & 11 \\
\hline & Lucania goodei & 0 & 0.00 & 8 & 0.06 & 8 \\
\hline & Ameiurus melas & 6 & 0.03 & 0 & 0.00 & 6 \\
\hline & Group total & 1359 & 6.56 & 2195 & 17.04 & 3554 \\
\hline \multirow[t]{10}{*}{ Brackish } & Mugil cephalus & 731 & 3.52 & 0 & 0.00 & 731 \\
\hline & Trinectes maculatus & 271 & 1.30 & 63 & 0.49 & 334 \\
\hline & Dormitator maculatus & 54 & 0.26 & 0 & 0.00 & 54 \\
\hline & Dorosoma petense & 10 & 0.05 & 0 & 0.00 & 10 \\
\hline & Leiostomus xanthurus & 5 & 0.03 & 0 & 0.00 & 5 \\
\hline & Anchoa mitchilli & 5 & 0.03 & 0 & 0.00 & 5 \\
\hline & Morone saxatilis & 4 & 0.02 & 0 & 0.00 & 4 \\
\hline & Alosa chrysochloris & 1 & $<0.01$ & 0 & 0.00 & 1 \\
\hline & Group total & 1081 & 5.21 & 63 & 0.49 & 1144 \\
\hline & Grand total & 20781 & 100 & 12892 & 100 & 33673 \\
\hline
\end{tabular}

In general, species richness increased with drainage area, but this trend was less evident in Elevenmile Creek. Species richness was higher at reference sites than Elevenmile Creek for all sampling periods (Figs 2 and 3). Species diversity $\left(H^{\prime}\right)$ was slightly lower at BCU than EM1 for periods 1, 2, and 4 (Fig. 2). Since species richness was higher at BCU than EM1, the lower species diversity of $\mathrm{BCU}$ can be attributed to low evenness, particularly the numerical dominance of two minnows, Pteronotropis hypselopterus and Notropis petersoni. Species diversity was higher at
BCL than EM4 for all compared periods, but both sites exhibited similar temporal fluctuation patterns (Fig. 3).

Time series analysis of mean L. macrochirus abundances showed a weak increasing trend at EM1, the outfall site (Fig. 4). The best fitting model, exponential growth, was a poor predictor of observed data (mean absolute percentage error $=47.40 \%$, mean absolute deviation $=58.41$, mean square deviation $=7491.71$ ). Decomposition of the residuals showed that L. macrochirus was typically more abundant in January than July 


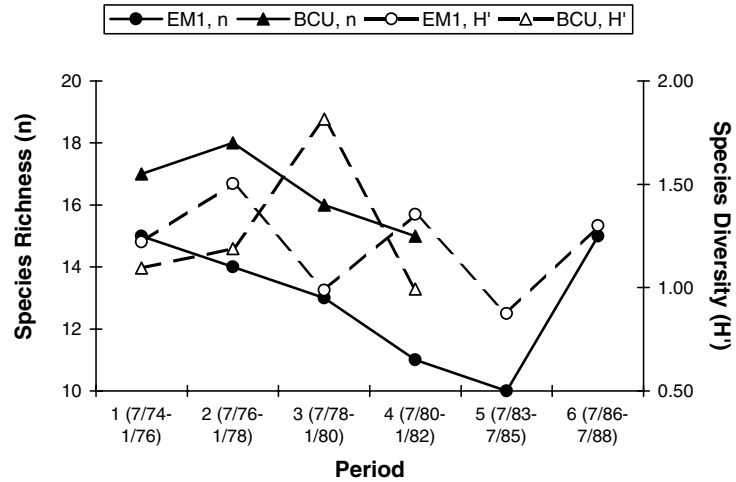

Figure 2. Species richness $(n)$ and Shannon-Weaver diversity $\left(H^{\prime}\right)$ for six periods at Elevenmile Creek station 1 (EM1) and four periods at Upper Black Creek (BCU) from 1974 until 1988.

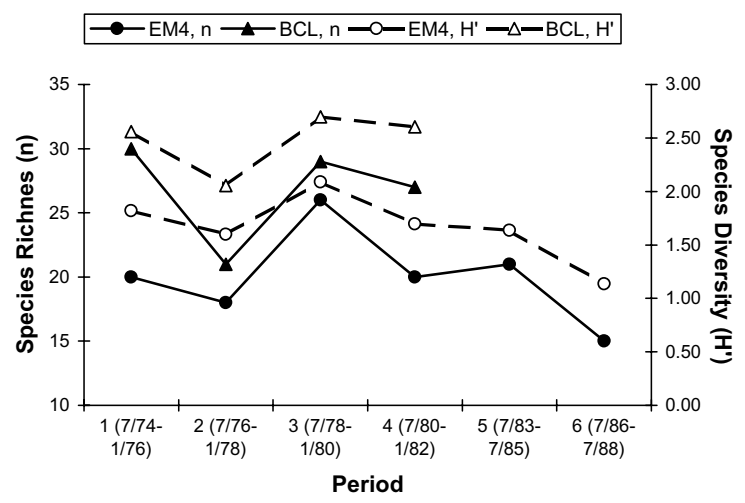

Figure 3. Species richness $(n)$ and Shannon-Weaver diversity $\left(H^{\prime}\right)$ for six periods at Elevenmile Creek station 4 (EM4) and four periods at Lower Black Creek (BCL) from 1974 until 1988.

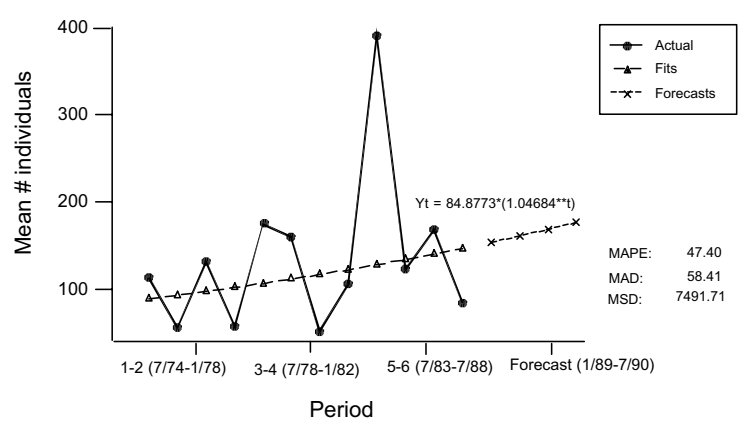

Figure 4. Time series analysis of Lepomis macrochirus abundances at Elevenmile Creek, station 1, over six periods from 1974 until 1988. Data points represent mean abundances for each period. Forecasts represent mean projected abundances from 1989 until 1990 including the mean absolute percentage error (MAPE), mean absolute deviation (MAD) and mean square deviation (MSD).
(Fig. 5), but population variation was also higher in January (Fig. 5b). Similar results were found at EM4 and pooled data from all Elevenmile Creek stations (data not shown). Due to variability among periods, these differences were not statistically significant at either EM1 or EM4 ( $t$-test, onetailed, $p>0.05)$. Significant seasonal differences were found, however, for L. macrochirus abundances for pooled data from all Elevenmile Creek stations ( $t$-test, one-tailed, $p<0.01)$.

\section{Discussion}

The fish communities of Elevenmile Creek, Black Creek, and Pond Creek are similar in overall species composition, but Elevenmile Creek had considerably lower abundances of CCP species. Species of the families Centrarchidae and Poeciliidae, especially Lepomis macrochirus and Gambusia affinis, were up to 10 times more abundant in Elevenmile Creek than either Black Creek or Pond Creek. These species often dominate fish communities in disturbed habitats, presumably because they are more tolerant of environmental stresses than CCP species (Alabaster \& Lloyd, 1980; Swift et al., 1986). The drainage basins considered in this study have comparable levels of species densities (0.1041 species $\mathrm{km}^{-2}$ for the Perdido River Basin, 0.1060 species $\mathrm{km}^{-2}$ for the Escambia River Basin, and 0.0997 species $\mathrm{km}^{-2}$ for the Choctawhatchee River Basin), reflecting the high species richness of small Gulf coastal drainage systems. The fish faunas of Black Creek and Pond Creek, however, with their greater proportion of CCP species, are more typical of communities in undisturbed coastal blackwater streams (Swift et al., 1986).

With the exception of the EM1-BCU comparison, species richness and diversity were higher at reference streams than Elevenmile Creek. The lower species diversity at BCU than EM1 was primarily due to a numerical dominance of the sailfin shiner, Pteronotropis hypselopterus, a CCP species. P. hypselopterus favors small to medium sized streams (Suttkus \& Mettee, 2001), so its abundance at BCU was not surprising. Given the proximity of Elevenmile Creek to Black Creek and the similarity in both drainage size and habitat, it is likely that $P$. hypselopterus would be more abundant in Elevenmile Creek if this stream was less disturbed during the survey period. 

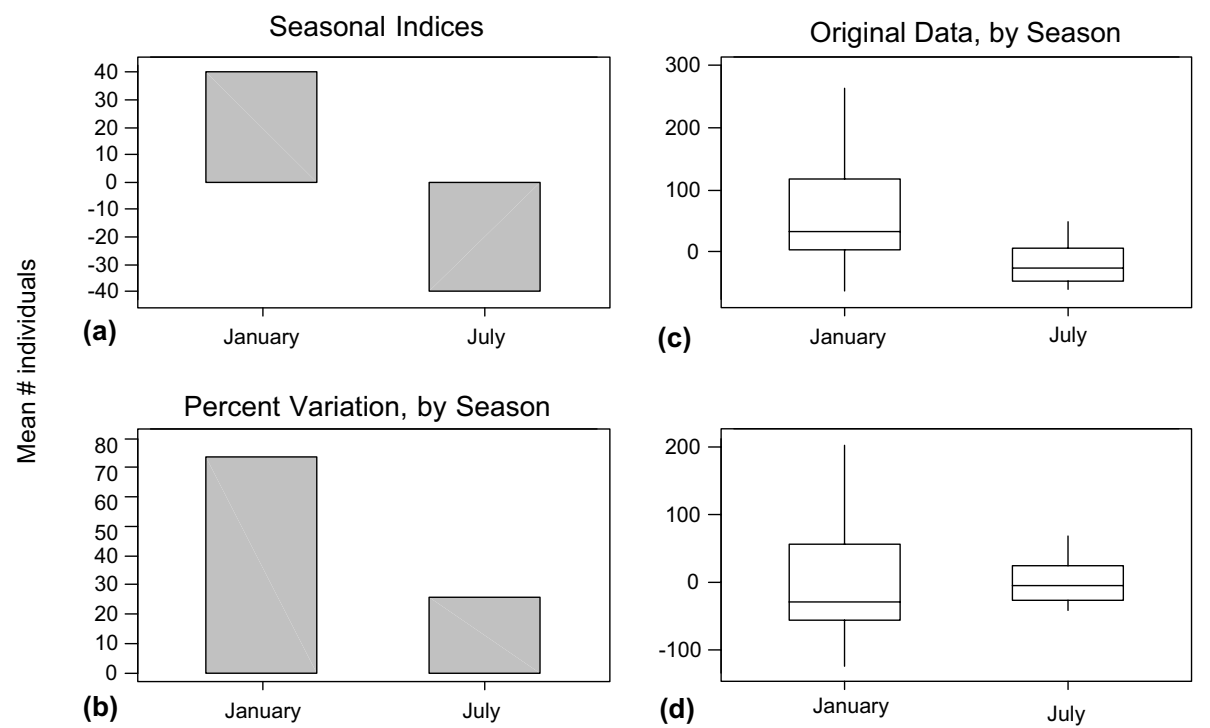

(c)

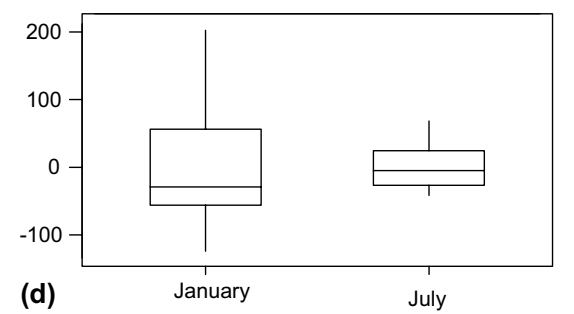

Figure 5. Decomposition of residuals from time series analysis of mean Lepomis macrochirus abundances from Elevenmile Creek, station 1, from 1974 until 1988 according to (a) seasonal indices (b) seasonal percent variation (c) box plots of original data in which the line represents the median, the lower and upper sections represent the 25 and 75 percentiles, respectively, and error bars represent the lower 5\% and upper 95\% (d) box plots of seasonal residuals, median and error bars as in (c).

No data exist for fish assemblages in Elevenmile Creek before the 1971 effluent modifications, but the consistently lower fish species diversity and richness suggests that the fish community did not recover following treatment upgrades. This observation agrees with Karels \& Niemi (2002) who studied fish community responses to improvements in KME quality in a freshwater lake in Finland. Karels \& Niemi (2002) reported that at effluent concentrations as low as $0.5-4.0 \%$, stresstolerant species, such as perch and ruffe, were more common in polluted than reference areas, though relative abundances declined following improvements in effluent quality. Furthermore, they did not find cyprinids close $(1-5 \mathrm{~km})$ to mills, whereas cyprinids were found at intermediate and reference sites. An absence of minnows in areas close to mill outfalls was also reported by Bagge \& Hakkari (1992). Recovery in fish communities following mill effluent upgrades, however, has been shown by Kovacs et al. (2002) and Sandstrom (1994).

We noted some changes in species occurrence over time. Some species that were present early in the survey were not seen in later years (e.g., Noturus leptacanthus, Elassoma evergladei and E. zonatum). Conversely, some species that were not present early on, appeared later in the survey (e.g., Esox americanus, Dormitator maculatus, and Ameiurus catus). These species were all rare $(<5 \%$ in abundance) and presence or absence may have been an artifact of sampling effort. The white catfish, A. catus, is not native to the Perdido Bay drainage (Swift et al., 1986), and the population was probably established by fish escaping from caged exposure studies (Livingston, 1989). The long-term consequences of introduction of $\mathrm{A}$. $\mathrm{Ca}$ tus for the diversity of fish fauna in Elevenmile Creek are unknown.

The most abundant fish species at Elevenmile Creek throughout the survey were bluegill, Lepomis macrochirus, and eastern mosquitofish, Gambusia affinis. Both species are tolerant of environmental stress (Henry et al., 1999; D'Surney et al., 2000) and often have high populations in thermally elevated conditions (Meffe \& Sheldon, 1990; Meffe, 1991; Taylor et al., 1991). The high $\left(30-32{ }^{\circ} \mathrm{C}\right)$ water temperatures observed at Elevenmile Creek during fall and winter of the survey (Livingston, 1989, unpublished report) may have resulted in an extended breeding season contributing to high abundances.

Populations of L. macrochirus fluctuated seasonally, but this species dominated the fish com- 
munity throughout the survey period. Conditions in Elevenmile Creek, especially at the mill outfall, are likely more favorable to sunfishes, including $L$. macrochirus, over other fish species. Habitat at the mill outfall and immediately upstream consists of large pools, which are not common in reference streams. Pools are preferred habitats for sunfishes (Werner \& Hall, 1974). Additionally, aquatic insect larvae are abundant at the mill outfall and bluegills from EM1 are in better physical condition than bluegills from a nearby reference site (Burse, 2003). The favorable habitat for bluegills and abundance of prey may therefore have contributed to the high numbers of L. macrochirus at Elevenmile Creek compared to reference streams.

Masculinization of female mosquitofish is well documented in Elevenmile Creek and other KME receiving streams (Howell et al., 1980; Drysdale \& Bortone, 1989; Howell \& Denton, 1989; Krotzer, 1990; Davis \& Bortone, 1992; Cody \& Bortone, 1997). We noted evidence of masculinization (elongation and other modifications of anterior rays of the anal fin) of female $G$. affinis in samples archived in the Tulane Fish Collection from the upper three Elevenmile Creek stations. However, the development of male secondary sex characteristics in females does not appear to limit the success of the mosquitofish population in Elevenmile Creek.

Data presented in this study represent fish surveys conducted from 1973 to 1988 and may therefore not reflect the present water quality and fish community composition of Elevenmile Creek. The fact that Elevenmile Creek had lower species richness and diversity than Black Creek during the 8 years that collections are available for both of these streams suggests that this was not a sufficient period of time for the fish community to recover despite effluent quality improvements occurring prior to and during this time. Other factors, such as favorable habitat and food availability, may also have facilitated the dominance of certain species, particularly L. macrochirus, in Elevenmile Creek.

In conclusion, this study supports earlier findings that (1) fish diversity is lower in KME receiving streams than in streams that do not receive KME and (2) the fish community of the affected system tends to be numerically dominated by stress-tolerant species. Moreover, changes in KME treatment practices that occurred in El- evenmile Creek prior to and during the survey did not result restore fish community diversity to levels observed in comparable streams that did not receive KME. However, it should be emphasized that ours is a retrospective analysis based on historic data, and thus does not address present conditions in the study streams.

\section{Acknowledgements}

This paper is based upon the Master's research of DIG. We thank T. Bianchi and T. Sherry for suggestions on earlier drafts of this manuscript, R. D. Suttkus for field collection information, and R. J. Livingston for information on the paper mill. We also thank C. Walser, C. Gradney, and J. Buckley for field assistance and M. Taylor for help with computer graphics.

\section{References}

Adams, M. S. et al., 1992. Relationships between physiological responses in a contaminated stream. Environmental Toxicology and Chemistry 11: 1549-1557.

Adams, M. S., A. M. Brown \& R. W. Goede, 1993. A quantitative health assessment index for rapid evaluation of fish condition in the field. Transactions of the American Fisheries Society 122: 63-73.

Alabaster, J. S. \& R. Lloyd, 1980. Water Quality Criteria for Freshwater Fish. University Press, Cambridge.

Bagge, P. \& L. Hakkari, 1992. Effects of paper mill effluents on the fish fauna of stony shores on Lake Paijanne. Hydrobio logia 243: 413-420.

Bortone, S. A. \& R. P. Cody, 1999. Morphological masculinization in poeciliid females from a paper mill effluent receiving tributatary of the St. Johns River, Florida, USA. Bulletin of Environmental Contamination and Toxicology 63: $150-156$.

Burse, J. R., 2003. Comparative reproductive physiology of the bluegill sunfish, Lepomis marcochirus, in a pulp and paper mill effluent receiving stream and a neighboring blackwater river. Unpublished Ph.D. Dissertation Tulane University, New Orleans, LA.

Caruso, J. H. \& R. D. Suttkus, 1988. Abnormal expression of secondary sex characters in a population of Anguilla rostrata (Pisces: Anguillidae) from a dark colored Florida stream. Copeia 1998: 1077-1079.

Cody, R. P. \& S. A. Bortone, 1997. Masculinization of mosquitofish as an indicator of exposure to kraft mill effluent. Bulletin of Environmental Contamination and Toxicology 58: 429-436.

Davis, W. P. \& S. A. Bortone, 1992. Effects of kraft mill effluent on the sexuality of fishes: an early environmental early 
warning? In Colhorn, T. \& C. Clements (eds), Advances in Modern Environmental Toxicology, Vol. XXI. Princeton Scientific, New Jersey: 113-127.

Drysdale, D. T. \& S. A. Bortone, 1989. Laboratory induction of intersexuality in the mosquitofish, Gambusia affinis, using paper mill effluent. Bulletin of Environmental Contamination and Toxicology 43: 611-617.

D'Surney, S. J. et al., 2000. Assessment of the impact of a bleached kraft mill effluent on a south-central USA river. Environmental Toxicology 15: 28-39.

Hall, T. J., R. K. Haley, D. L. Borton, A. H. Walsh \& R. E. Wolke, 1992. Histopathology of rainbow trout (Oncorhynchus mykiss) after long-term exposure to biologically treated bleached kraft mill effluent in experimental stream channels. Canadian Journal of Fisheries and Aquatic Sciences 49: 939944

Henry, T. B. et al., 1999. Acute toxicity of an acid mine drainage mixing zone to juvenile bluegill and largemouth bass. Transactions of the American Fisheries Society 128: 919-928.

Howell, W. M. \& T. E. Denton, 1989. Gonopodial morphogenesis in female mosquitofish, Gambusia affinis affinis masculinized by exposure to degradation products from plant sterols. Journal of the Fisheries Research Board of Canada 32: 795-796.

Howell, M. W., A. D. Black \& S. A. Bortone, 1980. Abnormal expression of secondary sex characters in a population of mosquitofish, Gambusia affinis holbrooki: evidence for environmentally-induced masculinization. Copeia 676-681.

Jobling, S. \& C. R. Tyler, 2003. Endocrine disruption in wild freshwater fish. Pure and Applied Chemistry 75: 2219-2234.

Karels, A. E. \& A. Niemi, 2002. Fish community responses to pulp and paper mill effluents at the southern Lake Saimaa, Finland. Environmental Pollution 116: 309-317.

Karels, A., E. Markkula \& A. Oikari, 2001. Reproductive, biochemical, physiological, and population responses in perch (Perca fluvatilis L.) and roach (Rutilus rutilus L.) downstream of two elemental chlorine-free pulp and paper mills. Environmental Toxicology and Chemistry 20: 1517-1527.

Khan, R. A. \& J. F. Payne, 1997. A multidisciplinary approach using several biomarkers including a parasite, as indicators of pollution: a case history from a paper mill in Newfoundland. Parassitologia 39: 183-188.

Khan, R. A. \& J. F. Payne, 2002. Factors influencing EROD activity in feral winter flounder (Pleuronectes americanus) exposed to effluent from a pulp and paper mill in Newfoundland. Bulletin of Environmental Contamination and Toxicology 68: 791-800.

Kovacs, T. G., P. H. Martel \& R. H. Voss, 2002. Assessing the biological status of fish in a river receiving pulp and paper mill effluents. Environmental Pollution 118: 123-140.

Krotzer, M. J., 1990. The effects of induced masculinization on reproductive and aggressive behaviors of the female mosquitofish Gambusia affinis affinis. Environmental Biology of Fishes 29: 127-134.

Lindesjoo, E. \& J. Thulin, 1992. A skeletal deformity of northern pike (Esox lucius) related to pulp mill effluents. Canadian Journal of Fisheries and Aquatic Sciences 149: 166-172.

Livingston, R. J., 1984. Trophic response of fishes to habitat variability in coastal seagrass systems. Ecology 65: 1258-1275.
Livingston, R. J., 1989. Ecological study of the Perdido drainage system: historical overview and data review. Unpubl. report to Environmental Planning Analysis, Inc., Tallahassee, Fl. 68 p plus appendices.

Mayden, R. L., B. M. Burr, L. M. Page \& R. R. Miller, 1992. Names of North American Freshwater Fishes. In Mayden, R. L. (ed.), Systematics and Historical Ecology of North American Freshwater Fishes. Stanford University Press.

Meffe, G. K. \& A. L. Sheldon, 1990. Offspring size variation in eastern mosquitofish (Gambusia holbrooki: Poeciliidae) from contrasting thermal environments. Copeia 1: 10-18.

Meffe, G. K., 1991. Life history changes in eastern mosquitofish (Gambusia holbrooki) induced by thermal elevation. Canadian Journal of Fisheries and Aquatic Sciences 48: 60-66.

Peet, P. K., 1974. The measurement of species diversity. Annual Review of Ecology and Systematics 12: 285-307.

Peet, P. K., 1975. Relative diversity indices. Ecology 56: 496-498.

Sandstrom, O., 1994. Incomplete recovery in a coastal fish community exposed to effluent from a modernized Swedish bleached kraft mill. Canadian Journal of Fisheries and Aquatic Sciences 51: 2195-2202.

Sepulveda, M. S., D. S. Ruessler, N. D. Denslow, S. E. Holm, T. R. Schoeb \& T. S. Gross, 2001. Assessment of reproductive effects in largemouth bass (Micropterus salmoides) exposed to bleached/unbleached kraft mill effluents. Archives of Environmental Contamination and Toxicology 41: 475-482.

Sharples, A. D. \& C. W. Evans, 2003. Impact of pulp and paper mill effluent on water quality and fauna in a New Zealand hydroelectric lake. New Zealand Journal of Marine and Freshwater Research 32: 31-53.

Sokal, R. R. \& F. J. Rohlf, 1995. Biometry: The Principles and Practice of Statistics in Biological Research, 3rd edn. W.H. Freeman, New York.

Suarez, A. V. \& N. D. Tsutsui, 2004. The value of museum collections for research and society. BioScience 54: 6674.

Suntio, L. R. et al., 1988. A review of the nature and properties of chemicals present in pulp mill effluents. Chemosphere 17: $1249-1290$

Suttkus, R. D. \& M. F. Mettee, 2001. Analysis of four species of Notropis included in the subgenus Pteronotropis Fowler, with comments on relationships origin and dispersion. Geological Survey of Alabama Bulletin 170: 1-50.

Swift, C. C. et al., 1986. Zoogeography of the freshwater fishes of the southern United States: Savannah River to Lake Pontchartrain. In Hocutt, C. H. \& E. O. Wiley (eds), The Zoogeography of North American Freshwater Fishes. John Wiley and Sons, Inc., New York: 213-265.

Taylor, B. E. et al., 1991. Population dynamics and food habitats of bluegill (Lepomis macrochirus) in a thermally stressed reservoir. Canadian Journal of Fisheries and Aquatic Sciences 48: 768-775.

Thulin, J., J. Hoglund \& E. Lindesjoo, 1988. Diseases and parasites of fish in a bleached kraft mill effluent. Water Science and Technology 2: 179-180.

Werner, E. E. \& D. J. Hall, 1974. Optimal foraging and size selection of prey by the bluegill sunfish (Lepomis macrochirus). Ecology 55: 1042-1052. 
Copyright of Hydrobiologia is the property of Kluwer Academic Publishing / Academic and its content may not be copied or emailed to multiple sites or posted to a listserv without the copyright holder's express written permission. However, users may print, download, or email articles for individual use. 
Copyright of Hydrobiologia is the property of Kluwer Academic Publishing / Academic and its content may not be copied or emailed to multiple sites or posted to a listserv without the copyright holder's express written permission. However, users may print, download, or email articles for individual use. 